\title{
Cytoprotective Activity of Cissus quadrangularis Linn Variant I Against Gastric and Duodenal Ulcer in Rat Models
}

\author{
Anoop Austin ${ }^{1, *}$ and M. Jegadeesan ${ }^{2}$ \\ ${ }^{I}$ Rumi Herbals $R \&$ D centre, 40/41, Spartan Avenue, Mugappair East, Chennai - 600037 and ${ }^{2}$ Department of Siddha \\ Medicine, Faculty of Sciences, Tamil University, Thanjavur - 613005, India
}

\begin{abstract}
The square stemmed variety of Cissus quadrangularis L. variant I is a medicinal plant widely used for peptic ulcer and bone fractures in Indian Systems of Medicine. Though this medicinal plan is abundantly used in India, detailed studies are lacking on the variants and seasonal variations, which are to be addressed. The present study is carried out to evaluate the antiulcerogenic property of aqueous ethanolic extracts of the aerial parts in various ulcer models in animals. The study clearly elucidated that the drug was found to increase the defensive factors by virtue of its ulcer score, carbohydrate protein ratio and decrease in aggressive factors like free acidity, pepsin apart from other biochemical parameters. Plants collected during flowering season are more effective than that collected during vegetative seasons. Extract significantly reduced the formation of gastric and duodenal lesions by virtue of its cyto-protective and mucin productive activities.
\end{abstract}

Key Words: Cissus quadrangularis, antiulcer activity, vitaceae, peptic ulcer disorders.

\section{INTRODUCTION}

Cissus quadrangularis Linn (Family: Vitaceae) is a climber with stout fleshy quadrangular stem found throughout the hotter parts of India [1]. Three morpho-variants of Cissus quadrangularis with square-stemmed, round-stemmed and flat-stemmed are available. They are differentiated as variant I, II and III respectively [2,3]. Variant I is quite common than the other two, which is considered to be a remedy for gastric ulcer [3,4]. The toxicological [5] and helicobactericidal [6] activities of C. quadrangularis variant I have been reported earlier. The antiulcer activity of Variant II has also been reported [7]. In the present study $C$. quadrangularis has been investigated for its antiulcer activities in animal models. Plants were collected during flowering and vegetative seasons and subjected to pharmacological studies to evaluate the seasonal variation with respect to its antiulcer activity in order to prove the effect and influence on seasonal variations.

\section{MATERIALS AND METHODS}

\section{Plant Material}

Aerial parts of $C$. quadrangularis were collected from Palayamkottai, Tirunelveli district, Tamilnadu, India and identified by the co-author. A voucher specimen has been deposited in the department herbarium for future reference (TUH No. 189). Plant samples were collected during twogrowth phases viz., flowering (November, 2000) and vegetative season (May, 2000). The plant materials were cleaned,

*Address correspondence to this author at the Rumi Herbals R \& D centre, 40/41, Spartan Avenue, Mugappair East, Chennai - 600 037, India;

E-mail: anoopaustin@gmail.com shade-dried, disintegrated and filtered in a sieve $(40 \mathrm{~mm})$ and stored in an airtight container and used for the entire study.

\section{Extraction}

Cold, aqueous (50\%) ethanolic extract was prepared according to the methodology described in Indian Pharmacopoeia (Yield: 18.64\%) [8]. Preliminary phytochemical screening [9] of the aqueous extract gave positive results for alkaloids, saponins, fixed oils, tannins and phenols and negative results for flavonoids. The dried extract was reconstituted with water whenever needed.

\section{Animals}

Six male Wistar strain albino rats of weighing 180-220 g were taken from the inbred group maintained at Tamil University animal house, Thanjavur. The animals were fed with standard pelleted diet supplied by Lipton \& Co. Ltd., Bangalore. Feed and water were made available to animals ad libitum.

\section{Antiulcer Activity}

Modified pyloric ligated (Shay) rat, aspirin induced ulcerogenesis in pyloric ligated (Shay) rat and cysteamine induced duodenal ulcer models [10] were used to study the antiulcer activity.

\section{Modified Pyloric Ligated (Shay) Rats}

Rats were divided into groups of six animals each and were placed in cages with grating floor to avoid coprophagy and fasted for 48 hours allowing free access to water. One group received water $(1 \mathrm{ml} / \mathrm{kg})$ and was served as control. 
Ranitidine (30 mg/kg) and omeprazole ( $2 \mathrm{mg} / \mathrm{kg}$ ) were selected as reference drugs and was given to two groups, for comparison. In the test group, the animals were grouped into three, receiving aqueous ethanolic extracts at a dose level of $150,300 \& 450 \mathrm{mg} / \mathrm{kg}$ b.w. The test drugs and reference drugs were administered once daily, orally, for two days prior to and one hour before pyloric ligation. The animals were deprived of both food and water during the postoperative period. The animals were anaesthetized with chloroform. Four hours after ligation, animals were sacrificed.

\section{Aspirin-Induced Ulcerogenesis in Pyloric Ligated Rats}

In aspirin-induced ulcerogenesis in pyloric ligated rats, aspirin is administered at a dose of $200 \mathrm{mg} / \mathrm{kg}$ orally in a suspension prepared in 1\% Carboxy Methyl Cellulose (CMC) with water 1 hour prior to pyloric ligation (Time interval between reference drugs and Aspirin should be one hour) and the process described above was followed.

\section{Biochemical Parameters}

The stomach was excised carefully keeping the oesophagus closed, opened along the greater curvature and the luminal contents were removed. The gastric contents were collected in a beaker and centrifuged at $1000 \mathrm{rpm}$ for $10 \mathrm{~min}-$ utes. The samples were analysed for gastric volume [11], $\mathrm{pH}$, free and total acidity [12] and sodium and potassium ion concentration [13]. Bio-chemical estimations like total proteins [14], total carbohydrate [15], total hexoses [16], hexosamine [17], fucose [18], sialic acid [19] and pepsin [20] were also made. The mucosa was flushed with saline and stomach pinned on a frog board and scored.

\section{Collection of Gastric Juice}

Gastric juice was collected from the pyloric-ligated rats [11]. The gastric juice thus collected was centrifuged and the volume of gastric juice as well as $\mathrm{pH}$ of gastric juice was measured. Then the gastric juice was subjected to biochemical estimation as follows.

\section{Determination of Free and Total Acidity in Gastric Juice}

$1 \mathrm{ml}$ of gastric juice was pipetted into a $100 \mathrm{ml}$ conical flask, added 2 to 3 drops of Topfer's reagent and titrated with $0.01 \mathrm{~N} \mathrm{NaOH}$ (which was previously standardized with $0.01 \mathrm{~N}$ of oxalic acid) until all traces of the red colour disappears and the colour of solution was yellowish orange. The volume of alkali added was noted. The volume corresponds to free acidity. Then 2 to 3 drops of phenolphthalein solution were added and titration was continued until a definite red tinge reappears. Again the total volume of alkali added was noted. The volume corresponds to total acidity.

Acidity was calculated by using the formula

Volume of $\mathrm{NaOH} \times$ Normality of $\mathrm{NaOH} \times 100$

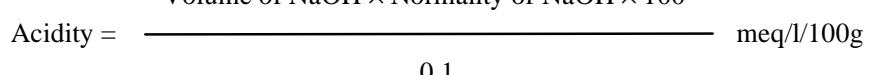

\section{Sodium and Potassium Ion Concentration in Gastric} Juice

This was carried out in Systronics mediflame 127- flame photometer. Stock solution was prepared. Sodium stock solution was prepared by dissolving $2.542 \mathrm{~g} \mathrm{NaCl}$ in 1 litre of distilled water. It contains $1 \mathrm{mg} \mathrm{Na}$ per $\mathrm{ml}$ (ie., $1000 \mathrm{ppm}$ ). Stock solution was diluted to give four solutions containing $10,5,2.5$ and $1 \mathrm{ppm}$ of sodium ions. Then potassium stock solution was prepared by dissolving $1.909 \mathrm{~g} \mathrm{KCl}$ in 1 litre of distilled water. It contains $1 \mathrm{mg}$ potassium per $\mathrm{ml}$ (ie., 1000 $\mathrm{ppm})$. Stock solution was diluted to give four solutions containing 20, 10, 5 and $2 \mathrm{ppm}$ of potassium ions.

For sodium and potassium, the flame intensity corresponding to the concentration of stock solution was noted by using appropriate filters. The results were plotted in a graph. The flame intensity of the gastric juice was noted. The concentration of sodium and potassium ions was calculated from the graph. The results are expressed in terms of $\mathrm{mg} / \mathrm{l}$.

\section{Total Proteins}

The dissolved protein in gastric juice was estimated in the alcoholic precipitate obtained by adding $90 \%$ alcohol with gastric juice in 9:1 ratio. Then $0.1 \mathrm{ml}$ of alcoholic precipitate of gastric juice was dissolved in $1 \mathrm{ml}$ of $0.1 \mathrm{~N} \mathrm{NaOH}$ and from this $0.05 \mathrm{ml}$ was taken in another test tube, to this 4 $\mathrm{ml}$ of alkaline mixture was added and kept for $10 \mathrm{~min}$. Then $0.4 \mathrm{ml}$ of phenol reagent was added and again 10 min was allowed for colour development. Reading was taken against blank prepared with distilled water at $610 \mathrm{~nm}$ in Hitachi 1520 spectrophotometer. The protein content was calculated from standard curve prepared with bovine albumin and was expressed in terms of $\mu \mathrm{g} / \mathrm{ml}$ of gastric juice.

\section{Total Carbohydrates}

The dissolved mucosubstances in gastric juice were estimated in the alcoholic precipitate obtained by adding $90 \%$ alcohol with gastric juice in 9:1 ratio. Briefly the method consists of taking two aliquots of gastric juice and treated as described. To $1 \mathrm{ml}$ of gastric juice, $9 \mathrm{ml}$ of $90 \%$ alcohol was added. The mixture was kept for 10 minutes before it was centrifuged. The supernatant was discarded. The precipitate was dissolved in $0.5 \mathrm{ml}$ of $0.1 \mathrm{~N} \mathrm{NaOH}$. To this $1.8 \mathrm{ml}$ of 6 $\mathrm{N} \mathrm{HCl}$ was added. The mixture was hydrolysed in water bath at $100^{\circ} \mathrm{C}$ for 2 hours. The hydrolysate was neutralised by $5 \mathrm{~N}$ $\mathrm{NaOH}$ using phenolphthalein as indicator and the volume was made upto $4.5 \mathrm{ml}$ with distilled water and used for the estimation of total hexoses, hexosamine and fucose as described. To the other aliquot of $0.5 \mathrm{ml}$ of gastric juice, $4.5 \mathrm{ml}$ of alcohol was added. The mixture was shaken for $10 \mathrm{~min}$ utes and centrifuged to obtain precipitate. The precipitate was dissolved in $0.5 \mathrm{ml}$ of $0.1 \mathrm{~N} \mathrm{H}_{2} \mathrm{SO}_{4}$. This reconstituted solution was transferred to glass-stoppered tubes and then hydrolysed in a water bath at $100^{\circ} \mathrm{C}$ for 1 hour. After hydrolysis, the volume restored to $0.5 \mathrm{ml} ; 0.2 \mathrm{ml}$ of this hydrolysate was used for the estimation of sialic acid.

After obtaining the concentration $(\mu \mathrm{g} / \mathrm{ml})$ of individual carbohydrates namely hexoses, hexosamine, fucose and sialic acid, the total carbohydrate content was calculated by adding the concentration of individual carbohydrates. Mucosubstances activity has been expressed as ratio of total carbohydrates to total proteins.

\section{Total Hexoses}

To $0.4 \mathrm{ml}$ of hydrolysate, $3.4 \mathrm{ml}$ of orcinol reagent was added. The mixture was then heated in the boiling waterbath 
at $60^{\circ} \mathrm{C}$ for 15 minutes. This was then cooled under running tap water and intensity of the colour was read in Hitachi 1520 spectrophotometer at $540 \mathrm{~nm}$ against the blank by using distilled water instead of hydrolysate. Total hexoses content was determined from the standard curve of $\mathrm{D}(+)$-galactosemannose and has been expressed in $\mu \mathrm{g} / \mathrm{ml}$ of gastric juice.

\section{Hexosamine}

$0.5 \mathrm{ml}$ of the hydrolysate fraction was taken. To this 0.5 $\mathrm{ml}$ of acetyl-acetone reagent was added. The mixture was heated in boiling waterbath at $60^{\circ} \mathrm{C}$ for 20 minutes, then cooled under running tap water. $1.5 \mathrm{ml}$ of $90 \%$ alcohol was added and allowed for 30 minutes. The colour intensity was measured in Hitachi 15-20 spectrophotometer at $530 \mathrm{~nm}$ against blank prepared by using distilled water instead of hydrolysate. Hexosamine content was determined from the standard curve prepared by using D (+)-glucosamine hydrochloride and concentration has been expressed in $\mu \mathrm{g} / \mathrm{ml}$ of gastric juice.

\section{Fucose}

In this method, three test tubes were taken. In one tube $0.4 \mathrm{ml}$ of distilled water was taken to serve as control and in each of the other two tubes $0.4 \mathrm{ml}$ of hydrolysates were taken. To all three tubes $1.8 \mathrm{ml}$ of $\mathrm{H}_{2} \mathrm{SO}_{4}$ : water (6:1) was added by keeping the test tubes in ice-cold waterbath to prevent breakage due to strong exothermic reaction. The mixture was then heated in boiling waterbath for exactly $3 \mathrm{~min}$. The tubes were taken out and cooled. To the blank and to one of the hydrolysate containing tube (unknown), $0.1 \mathrm{ml}$ of cysteine reagent was added while cysteine regent was not added to the last test tube containing the hydrolysate (unknown blank). It is then allowed for 90 min to complete the reaction. The reading was taken in Hitachi 15-20 spectrophotometer at 396 and $430 \mathrm{~nm}$ setting zero with the distilled water. The optical density for the fucose in the hydrolysate was calculated from the differences in the reading obtained at 396 and $430 \mathrm{~nm}$ and subtracting the values without cysteine. This was read against standard curve prepared with $\mathrm{D}(+)$ - fucose. The fucose content was expressed in terms of $\mu \mathrm{g} / \mathrm{ml}$ of gastric juice.

True optical density $=\frac{\left(\mathrm{OD}_{396}-\mathrm{OD}_{430}\right)^{\text {Unknown }}-\left(\mathrm{OD}_{396}-\mathrm{OD}_{430}\right)^{\text {Unknown blank }}}{\left(\mathrm{OD}_{396}-\mathrm{OD}_{430}\right)^{\text {water blank }}}$

\section{Sialic Acid}

To $0.5 \mathrm{ml}$ of the hydrolysate in $0.1 \mathrm{~N} \mathrm{H}_{2} \mathrm{SO}_{4}, 0.2 \mathrm{ml}$ of sodium periodate was added and mixed thoroughly by shaking. A time of $20 \mathrm{~min}$ was allowed to elapse before addition of $1 \mathrm{ml}$ of sodium arsenite solution to this mixture. The brown colour produced disappeared after shaking. Then $3 \mathrm{ml}$ of thiobarbituric acid was added and the mixture was heated in boiling waterbath for 15 minutes. After cooling the tubes, $4.5 \mathrm{ml}$ of cyclohexanone was added and thorough shaking was done for $15 \mathrm{sec}$ till all the colour was taken up by the cyclohexanone supernatant. The mixture was centrifuged to get a clear pink layer of cyclohexanone. This supernatant was pippeted out and intensity of colour was measured in Hitachi 15-20 spectrophotometer at $550 \mathrm{~nm}$. The sialic acid content of the sample was determined from the standard curve of sialic acid and has been expressed in terms of $\mu \mathrm{g} / \mathrm{ml}$ of gastric juice.

\section{Pepsin}

For each determination four tubes (1) and (2) containing $5 \mathrm{ml}$ of substrate, (3) and (4) containing $10 \mathrm{ml}$ of TCA was placed in the waterbath at $37^{\circ} \mathrm{C}$. The gastric juice was mixed with an equal volume of $\mathrm{HCl}$ at $\mathrm{pH} 2.1$, warmed to $37^{\circ} \mathrm{C}$ and added $1 \mathrm{ml}$ of mixture to each tubes (1) and (4), incubated for 15 minutes and at the end mixed the contents of tube (1) with tube (3) and allowed to stand in the bath for about 4 minutes. Contents of tube (1) and tube (3) gives test and contents of tube (2) and tube (4) gives blank. Both the contents were filtered after 25-30 minutes, $2 \mathrm{ml}$ of filtrate was pippeted into $10 \mathrm{ml}$ of $\mathrm{NaOH}$, mixed by gentle rotation, then 1 $\mathrm{ml}$ of phenol was added and again mixed by gentle rotation. After $30 \mathrm{~min}$, the intensity of colour was measured at 680 $\mathrm{nm}$ in Hitachi 15-20 spectrophotometer.

The difference between test and blank gives a measure of peptic activity. As standard, mixed $2 \mathrm{ml}$ of freshly prepared phenol solution containing $50 \mu \mathrm{g} / \mathrm{ml}$ with $10 \mathrm{ml}$ of $\mathrm{NaOH}$ and $1 \mathrm{ml}$ of phenol reagent was added. After 5-10 minutes, the colour intensity was measured at $680 \mathrm{~nm}$.

\section{Ulcer Score}

The scoring is done as described by Laurence and Bacharach [21]. 0 corresponds to normal rugal pattern, 1 for alteration in normal rugal pattern, 2 for scattered haemorrhage lesions, 3 for haemorrhage lesions and ulcers and 4 for penetrating and perforating ulcers

\section{Cysteamine-Induced Duodenal Ulcer Model}

In cysteamine-induced duodenal ulcer model [10], ulcers were induced by the administration of cysteamine hydrochloride (Sigma Chemicals) $400 \mathrm{mg} / \mathrm{kg}$ (10\% solution in normal saline) orally, two times, at an interval of four hours and the animals were fed with food and water ad libitum throughout the experiment and plant extract was administered 30 minutes before each dose of cysteamine hydrochloride. After 24 hours from the first dose the animals were sacrificed and the duodenum was exposed and scored according to Selye and Szabo, 1973. 0 corresponds to normal mucosa, 2 for superficial mucosal erosion, 3 for deep ulcer or transmural ulcer and 4 for perforated ulcer respectively.

\section{Statistics}

Data were expressed as the mean \pm standard error of the means (S.E.M.) and statistical analysis was carried out using student's $t$-test.

\section{RESULTS}

Extracts of C. quadrangularis possessed anti ulcer activities comparable with standard drugs in animal models well accepted in gastric and duodenal ulcers. The study clearly elucidated that the drug increased the defensive factors and decreased the offensive factors studied. Observations on pyloric ligated (Shay) rat model treated with extract are given in Tables $\mathbf{1}$ and $\mathbf{2}$. Increase in defensive factors (ulcer score, carbohydrate protein ratio) and decrease in aggressive factors 
Table 1. Effect of C. quadrangularis Variant I on Ulcer and Acidity in Modified Pyloric Ligated (Shay) Rats

\begin{tabular}{|c|c|c|c|c|c|c|c|c|c|}
\hline Parameter & $\begin{array}{l}\text { Control } \\
1 \mathrm{ml} / \mathrm{kg}\end{array}$ & Ranitidine & Omeprazole & 150 & 300 & 450 & 150 & 300 & 450 \\
\hline $\begin{array}{l}\text { Gastric volume } \\
(\mathrm{ml})\end{array}$ & $7.10 \pm 0.52$ & $6.48 \pm 0.99$ & $4.73 \pm 1.28$ & $5.73 \pm 0.16$ & $5.03 \pm 0.12^{* * * *}$ & $4.13 \pm 0.08^{* * * *}$ & $5.77 \pm 0.51$ & $4.68 \pm 0.20^{* * *}$ & $4.53 \pm 0.13^{* * *}$ \\
\hline $\mathrm{pH}$ & $3.10 \pm 0.20$ & $2.83 \pm 0.09$ & $2.69 \pm 0.09$ & $2.97 \pm 0.08^{* * * *}$ & $2.74 \pm 0.11^{* * *}$ & $2.63 \pm 0.09^{* * * *}$ & $2.95 \pm 0.08$ & $2.92 \pm 0.08$ & $2.81 \pm 0.11$ \\
\hline $\mathrm{Na}^{+}(\mathrm{mg} / \mathrm{l})$ & $1.83 \pm 0.21$ & $1.47 \pm 0.14$ & $1.50 \pm 0.13$ & $2.08 \pm 0.28^{* * * *}$ & $1.96 \pm 0.04^{* * *}$ & $1.49 \pm 0.03^{* * *}$ & $1.62 \pm 0.03$ & $1.62 \pm 0.05$ & $1.80 \pm 0.06$ \\
\hline $\mathrm{K}^{+}(\mathrm{mg} / \mathrm{l})$ & $0.45 \pm 0.02$ & $0.34 \pm 0.04^{*}$ & $0.36 \pm 0.06$ & $0.47 \pm 0.01^{* * *}$ & $0.39 \pm 0.01^{* * *}$ & $0.38 \pm 0.004^{* * *}$ & $* 0.55 \pm 0.03$ & $0.51 \pm 0.03$ & $0.43 \pm 0.04$ \\
\hline $\begin{array}{l}\text { Free acidity } \\
\quad(\mathrm{meq} / \mathrm{l})\end{array}$ & $41.94 \pm 0.63$ & $32.81 \pm 0.68^{* * * *}$ & $28.36 \pm 0.67^{* * *}$ & $37.58 \pm 0.34^{* * * *}$ & $38.52 \pm 0.30^{* * * *}$ & $35.33 \pm 0.61^{* * *}$ & $33.82 \pm 0.8^{* * *}$ & $33.68 \pm 0.34^{* * * *}$ & $29.00 \pm 0.40^{* * * *}$ \\
\hline
\end{tabular}

Values are expressed as Mean \pm SEM, $N=6 .{ }^{*} \mathrm{P}<0.05 ;{ }^{* *} \mathrm{P}<0.01 ;{ }^{* * *} \mathrm{P}<0.001$ compared with control group.

Table 2. Effect of $C$. quadrangularis Variant I on Protein \& Metabolic Status in Modified Pyloric Ligated (Shay) Rats

\begin{tabular}{|c|c|c|c|c|c|c|c|c|c|}
\hline \multirow{2}{*}{ Parameter } & \multirow{2}{*}{$\begin{array}{l}\text { Control } \\
1 \mathrm{ml} / \mathrm{kg}\end{array}$} & \multicolumn{2}{|c|}{$\begin{array}{l}\text { Standards } \\
\text { (mg/kg Rat) }\end{array}$} & \multicolumn{3}{|c|}{$\begin{array}{c}\text { Vegetative Period } \\
\text { (mg/kg Rat) }\end{array}$} & \multicolumn{3}{|c|}{$\begin{array}{c}\text { Flowering Period } \\
\text { (mg/kg Rat) }\end{array}$} \\
\hline & & Ranitidine & Omeprazole & 150 & 300 & 450 & 150 & 300 & 450 \\
\hline $\begin{array}{l}\text { Pepsin } \\
(\mu \mathrm{g} / \mathrm{ml})\end{array}$ & $9.56 \pm 0.27$ & $4.39 \pm 0.16^{* * *}$ & $3.57 \pm 0.13^{* * * *}$ & $5.17 \pm 0.09^{* * * *}$ & $4.99 \pm 0.08^{* * * *}$ & $4.58 \pm 0.14^{* * *}$ & $5.10 \pm 0.29^{* * *}$ & $4.21 \pm 0.05^{* * *}$ & $4.71 \pm 0.12^{* * * *}$ \\
\hline $\begin{array}{l}\text { Total proteins } \\
\qquad(\mu \mathrm{g} / \mathrm{ml})\end{array}$ & $544.92 \pm 12.37$ & $220.81 \pm 6.38^{* * * *}$ & $278.23 \pm 4.47^{* * * *}$ & $304.68 \pm 4.02^{* * *}$ & $303.68 \pm 2.99^{* * * *}$ & $303.22 \pm 3.00^{* * * *}$ & $270.01 \pm 5.99^{* * * *}$ & $219.71 \pm 0.68^{* * * *}$ & $262.72 \pm 4.65^{* * * *}$ \\
\hline $\begin{array}{l}\text { Total hexoses } \\
\qquad(\mu \mathrm{g} / \mathrm{ml})\end{array}$ & $199.18 \pm 0.66$ & $309.01 \pm 7.67^{* * * *}$ & $385.69 \pm 4.01^{* * * *}$ & $221.90 \pm 1.66^{* * * *}$ & $327.83 \pm 3.91^{* * *}$ & $323.67 \pm 2.66^{* * * *}$ & $251.51 \pm 1.61^{* * * *}$ & $345.33 \pm 3.88^{* * * *}$ & $315.40 \pm 3.17^{\text {*** }}$ \\
\hline $\begin{array}{l}\text { Hexosamine } \\
\qquad(\mu \mathrm{g} / \mathrm{ml})\end{array}$ & $218.28 \pm 5.85$ & $306.45 \pm 4.12^{* * * *}$ & $492.53 \pm 9.03^{* * * *}$ & $292.81 \pm 6.96^{* * * *}$ & $334.87 \pm 2.49^{* * *}$ & $342.30 \pm 6.57^{* * * *}$ & $295.01 \pm 2.13^{* * *}$ & $437.17 \pm 2.68^{* * * *}$ & $540.44 \pm 4.94^{* * * *}$ \\
\hline $\begin{array}{l}\text { Fucose } \\
(\mu \mathrm{g} / \mathrm{ml})\end{array}$ & $41.54 \pm 0.62$ & $25.33 \pm 1.33^{* * * *}$ & $23.10 \pm 1.21^{* * *}$ & $27.98 \pm 0.95^{* * *}$ & $30.35 \pm 0.18^{* * * * *}$ & $24.19 \pm 1.23^{* * * *}$ & $31.28 \pm 0.21^{* * * * *}$ & $31.24 \pm 0.74^{* * * *}$ & $30.03 \pm 0.55^{* * *}$ \\
\hline $\begin{array}{l}\text { Sialic acid } \\
(\mu \mathrm{g} / \mathrm{ml})\end{array}$ & $22.24 \pm 0.61$ & $31.70 \pm 0.83^{* * *}$ & $32.72 \pm 0.69^{* * * *}$ & $28.17 \pm 1.01^{* * *}$ & $30.98 \pm 0.54^{* * * *}$ & $26.79 \pm 0.39^{* * *}$ & $29.17 \pm 0.49^{\text {***** }}$ & $31.42 \pm 0.24^{* * *}$ & $30.04 \pm 0.50^{* * *}$ \\
\hline $\begin{array}{l}\text { Carbohydrate } \\
\text { protein ratio }\end{array}$ & $0.89 \pm 0.02$ & $3.05 \pm 0.07^{* * *}$ & $3.36 \pm 0.06^{* * * *}$ & $1.87 \pm 0.01^{* * * *}$ & $2.39 \pm 0.03^{* * * *}$ & $2.37 \pm 0.04^{* * * *}$ & $2.25 \pm 0.04^{* * *}$ & $3.85 \pm 0.06^{* * * *}$ & $3.49 \pm 0.04^{* * * *}$ \\
\hline
\end{tabular}

Values are expressed as Mean $\pm \mathrm{SEM}, \mathrm{N}=6 .{ }^{* * * *} \mathrm{P}<0.001$ compared with control group.

(free acidity, pepsin) were observed. Aspirin induced ulcerogenesis in pyloric ligated (Shay) rats model results are given in Tables $\mathbf{3}$ and $\mathbf{4}$. Ulcer score was decreased in a dose dependent manner. Free acidity, pepsin content and carbohydrate / protein ratio were also altered. The activity of flowering sample is found to be active than vegetative sample.

In duodenal ulcer model, extract of flowering period showed a significant reduction in ulcer score from 300 $\mathrm{mg} / \mathrm{kg}$ onwards. Vegetative period also showed a reduction in ulcer score at the same dose levels (Fig. 1) but with less significance.

\section{DISCUSSION}

The extracts of $C$. quadrangularis significantly reduced the formation of gastric and duodenal lesions in rats induced by various ulcerogenic procedures and cyto-destructing agent. A dose dependent ulcer protective response was noted. Dose of $300 \mathrm{mg} / \mathrm{kg}$ was significant in reducing the ulcer in modified pyloric ligated (Shay) rat model. A corresponding dose in aspirin induced ulcerogenesis in pyloric ligated (Shay) rat model, $450 \mathrm{mg}$, which is due to the degeneration in the gastric mucosa. In duodenal ulcer model both the extracts were almost effective in ulcer protection. 
Table 3. Effect of C. quadrangularis Variant I on Protein \& Carbohydrate Status in Aspirin Induced Ulcerogenesis

\begin{tabular}{|c|c|c|c|c|c|c|c|c|c|}
\hline \multirow{2}{*}{ Parameter } & \multirow{2}{*}{$\begin{array}{l}\text { Control } \\
1 \mathrm{ml} / \mathrm{kg}\end{array}$} & \multicolumn{2}{|c|}{$\begin{array}{c}\text { Standards } \\
(\mathbf{m g} / \mathbf{k g})\end{array}$} & \multicolumn{3}{|c|}{$\begin{array}{c}\text { Vegetative Period } \\
\quad(\mathrm{mg} / \mathrm{kg})\end{array}$} & \multicolumn{3}{|c|}{$\begin{array}{c}\text { Flowering Period } \\
(\mathrm{mg} / \mathrm{kg})\end{array}$} \\
\hline & & Ranitidine & Omeprazole & 150 & 300 & 450 & 150 & 300 & 450 \\
\hline $\begin{array}{l}\text { Gastric volume } \\
(\mathrm{ml})\end{array}$ & $7.80 \pm 0.22$ & $4.24 \pm 0.17^{* * * *}$ & $3.60 \pm 0.17^{* * * *}$ & $5.13 \pm 0.56^{* *}$ & $4.07 \pm 0.06^{* * *}$ & $3.77 \pm 0.08^{* * * *}$ & $5.28 \pm 0.20^{* * *}$ & $4.23 \pm 0.11^{* * * *}$ & $4.57 \pm 0.17^{* * * *}$ \\
\hline $\mathrm{pH}$ & $1.74 \pm 0.04$ & $3.94 \pm 0.12^{* * * *}$ & $3.73 \pm 0.03^{* * *}$ & $3.47 \pm 0.12^{* * *}$ & $3.65 \pm 0.15^{* *}$ & $3.78 \pm 0.12^{* * *}$ & $3.26 \pm 0.07$ & $3.42 \pm 0.06$ & $3.61 \pm 0.04$ \\
\hline $\mathrm{Na}^{+}(\mathrm{mg} / \mathrm{l})$ & $0.60 \pm 0.02$ & $0.27 \pm 0.06^{* * * *}$ & $0.22 \pm 0.02^{* * *}$ & $1.81 \pm 0.01^{* * * *}$ & $1.69 \pm 0.01^{* * * *}$ & $1.70 \pm 0.02^{* * *}$ & $1.66 \pm 0.15$ & $1.41 \pm 0.01$ & $1.43 \pm 0.01$ \\
\hline $\mathrm{K}^{+}(\mathrm{mg} / \mathrm{l})$ & $0.28 \pm 0.02$ & $0.38 \pm 0.01^{* * *}$ & $0.65 \pm 0.09^{* * * *}$ & $0.39 \pm 0.02^{* *}$ & $0.44 \pm 0.02^{* * * *}$ & $0.49 \pm 0.01^{* * *}$ & $0.50 \pm 0.01^{*}$ & $0.38 \pm 0.01^{* *}$ & $0.35 \pm 0.01^{* * * *}$ \\
\hline $\begin{array}{l}\text { Free acidity } \\
\quad(\mathrm{meq} / \mathrm{l})\end{array}$ & $52.81 \pm 0.32$ & $41.89 \pm 0.54^{* * * *}$ & $36.52 \pm 0.47^{* * * *}$ & $39.61 \pm 0.29^{* * * *}$ & $36.52 \pm 0.34^{* * * *}$ & $31.20 \pm 0.52^{* * * *}$ & $37.87 \pm 0.37^{* * * *}$ & $36.88 \pm 0.53^{* * * *}$ & $33.06 \pm 0.23^{* * * *}$ \\
\hline
\end{tabular}

Values are expressed as Mean $\pm \mathrm{SEM}, \mathrm{N}=6 .{ }^{*} \mathrm{P}<0.05 ; .{ }^{* *} \mathrm{P}<0.01 ;{ }^{* * * *} \mathrm{P}<0.001$ compared with control group.

Table 4. Effect of $C$. quadrangularis Variant I on Protein and Carbohydrate Status in Aspirin Induced Ulcerogenesis

\begin{tabular}{|c|c|c|c|c|c|c|c|c|c|}
\hline \multirow{2}{*}{ Parameter } & \multirow{2}{*}{$\begin{array}{l}\text { Control } \\
1 \mathrm{ml} / \mathrm{kg}\end{array}$} & \multicolumn{2}{|c|}{$\begin{array}{c}\text { Standards } \\
(\mathbf{m g} / \mathbf{k g})\end{array}$} & \multicolumn{3}{|c|}{$\begin{array}{c}\text { Vegetative Period } \\
\quad(\mathbf{m g} / \mathbf{k g})\end{array}$} & \multicolumn{3}{|c|}{$\begin{array}{c}\text { Flowering Period } \\
(\mathbf{m g} / \mathbf{k g})\end{array}$} \\
\hline & & Ranitidine & Omeprazole & 150 & 300 & 450 & 150 & 300 & 450 \\
\hline $\begin{array}{l}\text { Pepsin } \\
(\mu \mathrm{g} / \mathrm{ml})\end{array}$ & $10.13 \pm 0.09$ & $4.85 \pm 0.04^{* * * *}$ & $4.10 \pm 0.07^{* * * *}$ & $5.86 \pm 0.04^{* * * *}$ & $4.95 \pm 0.07^{* * * *}$ & $5.13 \pm 0.05^{* * *}$ & $6.10 \pm 0.07^{* * * *}$ & $5.18 \pm 0.07^{* * * *}$ & $4.77 \pm 0.11^{* * * *}$ \\
\hline $\begin{array}{l}\text { Total hexoses } \\
(\mu \mathrm{g} / \mathrm{ml})\end{array}$ & $156.99 \pm 2.51$ & $287.36 \pm 4.91$ & $275.01 \pm 2.48^{* * * *}$ & $280.67 \pm 2.38^{* * * *}$ & $354.31 \pm 4.17^{* * * *}$ & $327.89 \pm 2.61^{* * * *}$ & $267.58 \pm 2.19^{* * * *}$ & $302.46 \pm 1.49^{* * * *}$ & $301.79 \pm 0.85^{* * *}$ \\
\hline $\begin{array}{l}\text { Hexosamine } \\
(\mu \mathrm{g} / \mathrm{ml})\end{array}$ & $250.77 \pm 3.03$ & $342.61 \pm 0.21^{* * * *}$ & $397.58 \pm 7.55^{* * *}$ & $297.30 \pm 3.37^{* * * *}$ & $354.16 \pm 3.60^{* * * *}$ & $384.44 \pm 4.60^{* * * *}$ & $292.51 \pm 1.70^{* * *}$ & $305.06 \pm 2.57^{* * *}$ & $333.31 \pm 10.26^{* * *}$ \\
\hline $\begin{array}{l}\text { Carbohydrate } \\
\text { protein ratio }\end{array}$ & $0.72 \pm 0.002$ & $2.26 \pm 0.02^{* * * *}$ & $2.97 \pm 0.04^{* * *}$ & $1.88 \pm 0.01^{* * *}$ & $2.64 \pm 0.06^{* * *}$ & $2.69 \pm 0.03^{* * * *}$ & $2.06 \pm 0.01^{* * *}$ & $2.37 \pm 0.01^{* * *}$ & $2.43 \pm 0.07^{* * * *}$ \\
\hline
\end{tabular}

Values are expressed as Mean $\pm \mathrm{SEM}, \mathrm{N}=6 .{ }^{* *} \mathrm{P}<0.01 ;{ }^{* * *} \mathrm{P}<0.001$ compared with control group.

Apart from antiulcer activity $C$. quadrangularis extract demonstrated other properties such as antisecretory activity. It reduced aggressive factors like pepsin, proteins and acidity, thereby enhancing the cytoprotective effect. Increase in potassium content is significant because it alters the hydrogen ion concentration thereby increasing the level of protection [22]. Carbohydrate/protein ratio also supports the result.

Variation between the two seasons may be due to the change in the concentration of the biological compounds. The mucosal defense mechanism may be due to the epithelial cells of the gastric mucosa, which are impermeable to hydrogen ions thereby forming a physical barrier [22]. The increase in potassium ion inturn reflects in increase in hydrogen ion and bicarbonate ion concentrations [23]. The increase in bicarbonate ion concentration plays an important role in protecting the gastric and duodenal mucosa against hydrochloric acid [23].

Extract increased hexosamine and carbohydrate/protein ratio and decreasing pepsin content, which increase mucous secretion. Protective role of mucous on gastric mucosa and is suggested as the defense mechanism [24].

The increased carbohydrate/protein ratio suggests an increase in dissolved mucosubstances. The presence of dis- 
solved mucosubstances in the gastric juice is a reliable index for an effective mucosal barrier [25]. This is an direct reflection of mucin activity [26] and suggests an increase in glycoprotein content of the gastric mucosa. Decrease in protein content of gastric juice suggests the decrease of leakage of plasma protein into gastric juice [27].

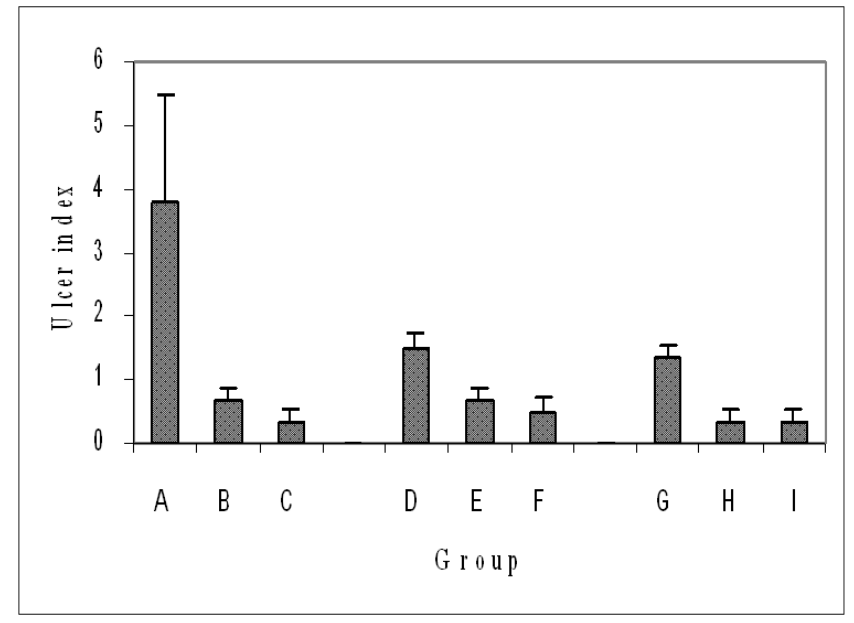

A - Control; B - Ranitidine (30 mg/kg); C - Omeprazole ( $2 \mathrm{mg} / \mathrm{kg})$; D, E, F -Vegetative period samples at a dose of 150,300 and $450 \mathrm{mg} / \mathrm{kg}$ dosage respectively; G, H, I - Flowering period samples at a dose of 150, 300 and $450 \mathrm{mg} / \mathrm{kg}$ dosage respectively.

Fig. (1). Ulcer index for duodenal ulcer model in C. quadrangularis variant $\mathrm{I}$.

The extract prevented duodenal ulcers induced by cysteamine, which has many similarities with duodenal ulcers in man [25]. Cysteamine induced ulcers are considered to be due to continuous hypersecretion of gastric acid.

Variant I collected during flowering period were more effective than that collected during vegetative period. During shift from vegetative to flowering phase there is a shift from primary biochemical pathways to secondary biochemical pathways thereby leading to synthesis of a number of new biological active compounds.

In conclusion, the present study confirms a slightly superior antiulcer activity of $C$. quadrangularis collected during flowering period. More studies are required to identify the active principle present in $C$. quadrangularis responsible for potent antiulcer activity.

\section{REFERENCES}

[1] Gupta MM, Verma RK. Unsymmetric tetracyclic triterpenoid from Cissus quadrangularis. Phytochemistry 1990; 29: 336-8.
[2] Kannan R, Jegadeesan M. Notes on the occurrence of variants in Cissus quadrangularis L. J Econ Tax Bot 1999; 22: 691-2.

[3] Anoop A, Kannan R, Jegadeesan M. Pharmacognostical studies on Cissus quadrangularis L. variant I \& II. Ancient Sci Life 2004; 23 : $33-47$.

[4] Nadkarni AN. Indian Materia Medica. Popular Book Depot; Bombay: India 1989.

[5] Anoop A, Jegadeesan M. Behavioral and sub-acute toxicity studies on Cissus quadrangularis Linn variant I. Amala Res Bull 2002; 22: 104-10.

[6] Anoop A, Jegadeesan M, Gowrishankar R. Helicobactericidal activity of Cissus quadrangularis L. variant I. Nat Prod Sci 2004; 10: 215-7.

[7] Anoop A, Jegadeesan M. Gastric and duodenal antiulcer and cytoprotective effects of Cissus quadrangularis $\mathrm{L}$. variant II in rats. $\mathrm{Ni}$ ger J Nat Prod Med 2002 ${ }^{\mathrm{a}}$; 6: 11-5.

[8] Anonymous. The Pharmacopoeia of India, 2nd ed. Ministry of Health \& Family Welfare; New Delhi: India 1996.

[9] Trease CE, Evans VC. Textbook of Pharmacognosy. Bailliere tindall; London: UK 1984.

[10] Parmar NS, Desai JK. A review of the current methodology for evaluation of gastric and duodenal antiulcer agents. Indian J Pharmacol 1993; 25: 120-35.

[11] Szabo S, Trier JS, Brown, Schnoor J, Hman HD, Bradford JC. A qualitative method for assessing the extend of experimental gastric erosions and ulcers. J Pharmacol Methods 1985; 13: 59-66.

[12] Hawk S. Hawk's physiological chemistry. MacGraw Hill Book Company; New York: 1947.

[13] Jeffery GH, Bassett J, Mendham J, Denney RC. Vogel's textbook of quantitative chemical analysis. $5^{\text {th }}$ ed. Longman Scientific \& technical publications; London: 1991.

[14] Lowry OH, Roseborough NI, Farr AL, Randall RJ. Protein measurement with folin phenol reagent, J Biol Chem 1951; 193: 265.

[15] Goel RK, Chakrabarti A, Sanyal AK. The effect of biological variables on the antiulcerogenic effect of vegetable plantain banana. Planta Med 1985; 2: 85-8.

[16] Winzler RJ. Determination of serum glycoproteins. Methods Biochem Anal 1958; 2: 29-31.

[17] Dische Z, Borentrend E. Determination of hexosamines. J Biol Chem 1950; 184: 517.

[18] Dische Z, Shettles LB. Spectrometric analysis for microdetermination of fucose, J Biol Chem 1948; 175: 595.

[19] Warren J. Unidentified curved bacilli on gastric epithelium in active chronic gastritis. Lancet 1959; 1: 1273.

[20] Debnath PK, Gode, KD, Govinda D, Sanyal AK. Effect of propranolol on gastric secretion in albino rat. Br J Pharmacol 1974; 52: 213-6.

[21] Laurence DR, Bacharach AL. Evaluation of drug activities - Pharmacometics. Academic press; London: 1964; vol. 2.

[22] Davenport HW, Warner HA, Code CF. Antiulcer activities of liquorice and its derivatives in experimental gastric lesion induced by ibuprofen in rats. J Gastroenterol 1964; 47: 142-52.

[23] Suzuki, M, Ishii, H. Pathophysiology of Helicobacter pylori induced gastric mucosal injury. Asian Med J 1996; 39: 186-91.

[24] Florey H, Webb RA. Protective role of mucous on gastric mucosa. Br J Exp Pathol 1933; 12: 286.

[25] Sanyal AK, Debnath PK, Bhattacharya SK, Gode KD. Peptic ulcer. Munsgaard; Copenhagen, Germany: 1971.

[26] Jain SM, Parmar NS, Santani DD. Gastric antiulcer activity of calcium channel blockers in rats. Indian J Pharmacol 1994; 26: 2934.

[27] Grossman MI. Control of gastric secretion, gastro-intestinal disease, patho-physiology, diagnosis and management. WB Saunders; Philadelphia: USA 1978.

This is an open access article licensed under the terms of the Creative Commons Attribution Non-Commercial License (http://creativecommons.org/licenses/ by-nc/3.0/) which permits unrestricted, non-commercial use, distribution and reproduction in any medium, provided the work is properly cited. 